\title{
CAN WE USE DENDROGEOMORPHOLOGY FOR THE SPATIAL AND TEMPORAL ANALYSIS OF LESS INTENSIVE MASS MOVEMENT PROCESSES? A CASE STUDY OF THREE DEBRIS FLOWS IN NW AND W SLOVENIA ALI LAHKO Z UPORABO DENDROGEOMORFOLOGIJE ANALIZIRAMO DELOVANJE MANJ INTENZIVNIH POBOČNIH MASNIH PREMIKOV V ČASU IN PROSTORU? ŠTUDIJA PRIMERA TREH DROBIRSKIH TOKOV V SZ IN Z SLOVENIJI
}

\author{
Matevž KONJAR ${ }^{1}$, Tom LEVANIČ2 ${ }^{2}$, Thomas Andrew NAGEL ${ }^{3}$, Milan KOBAL ${ }^{4}$ \\ (1) University of Ljubljana, Biotechnical Faculty, Department of Forestry and Renewable Forest Resources, konjarmatevz@gmail.com \\ (2) Slovenian Forestry Institute, tom.levanic@gozdis.si \\ (3) University of Ljubljana, Biotechnical Faculty, Department of Forestry and Renewable Forest Resources, tom.nagel@bf.uni-lj.si \\ (4) University of Ljubljana, Biotechnical Faculty, Department of Forestry and Renewable Forest Resources, milan.kobal@bf.uni-lj.si
}

\begin{abstract}
Debris flows can transport large amounts of material and therefore present a significant threat to infrastructure and human life. In this research, we used tree-ring width analyses to quantify the response of trees to three debris flow events in NW Slovenia (Javoršček, Srpenica) and W Slovenia (Nikova) for which we know the time of origin. We attempted to date these and similar tree responses in the past and compared the patterns between different tree species. Altogether, we sampled 147 trees across a range of tree species (Fagus sylvatica, Pinus sylvestris, Fraxinus excelsior, Fraxinus ornus, Acer pseudoplatanus, Picea abies, Juglans regia, Acer campestre, Tilia cordata and Ostrya carpinifolia), including reference trees that were outside the debris flow fan. For 91 trees, we constructed tree-ring chronologies and used pointer-year analysis to identify years that had abnormal growth. For the remaining trees (mostly Ostrya carpinifolia, Tilia cordata and Acer pseudoplatanus), we either could not accurately distinguish tree rings or two samples from a single tree showed significantly different growth patterns. The growth patterns of Fagus sylvatica and Picea abies following debris flow events showed a weak response at the Javoršček site and no clear responses at the other two sites. Tree species responded similarly at the same locations. Due to the lack of a clear response pattern, we were not able to reconstruct past debris flows.
\end{abstract}

Key words: debris flows, tree rings, dendrogeomorphology, slope processes

\section{IZVLEČEK}

Drobirski tokovi s sposobnostjo prenašanja večjih količin materiala so nevarni za infrastrukturo in življenje ljudi. Z analizo širine lesnih branik smo v raziskavi poskušali prepoznati odziv dreves na vpliv treh drobirskih tokov v SZ Sloveniji (Srpenica, Javoršček) in Z Sloveniji (Nikova) z znanim časom nastanka, na podlagi spremembe širine branike datirati podobne drobirske tokove v preteklosti in primerjati odzive različnih drevesnih vrst. Na treh lokacijah smo vzorčili skupno 147 dreves različnih drevesnih vrst (Fagus sylvatica, Pinus sylvestris, Fraxinus excelsior, Fraxinus ornus, Acer pseudoplatanus, Picea abies, Juglans regia, Acer campestre, Tilia cordata in Ostrya carpinifolia), vključno z referenčnimi drevesi, ki niso bila izpostavljena delovanju dejavnika. Pri 91 drevesih smo uspešno izdelali drevesne kronologije in z uporabo metode značilnih let ugotovili leta, ki so pri posameznih drevesnih vrstah ter na posameznih lokacijah glede na širno branike kazala zelo različne trende rasti. Pri drugih drevesih vrstah (večinoma Ostrya carpinifolia, Tilia cordata in Acer pseudoplatanus) nam ni uspelo razbrati vseh branik, oz. sta bili po dve zaporedji širin branik istega drevesa različni. V analizi rasti za prvo leto po dogodku smo šibak odziv na vpliv drobirskih tokov zaznali na lokaciji pod Javorščkom, ne pa tudi v Srpenici in Nikovi. Različne drevesne vrste so se na istih lokacijah odzvale podobno. Ker smo zaznali odziv le na eni lokaciji, nismo mogli rekonstruirati drobirskih tokov po posameznih lokacijah v preteklosti.

Ključne besede: drobirski tokovi, lesne branike, dendrogeomorfologija, pobočni procesi

\section{INTRODUCTION}

1 UVOD

Debris flows are a frequent mass movement (geomorphological) process in alpine regions (Mikoš,
2001). They are characterized by unpredictable spatial and temporal occurrence, fast displacement of sediments, and high flow velocity and energy. As a consequence, they can have a large impact on the enviro- 
nment. The fluid in debris flows enables them to have a long reach, even on terrain with a relatively gradual gradient. The solid debris can cause mechanical damage, denude the soil, block drainage ways, damage infrastructure and threaten human life (Iverson, 1997). Debris flows often damage trees, which is normally expressed by tilting of the tree, mechanical damage on stems, burial or exposure of stems and roots, damage caused by prolonged water submersion, and breakage of branches and treetops (Shroder, 1980).

These different types of tree damage can also affect the growth of trees and can be analysed using dendrogeomorphology, a combination of geomorphology and dendrochronology (Alestalo, 1971). The fundamental principles of dendrogeomorphology were described by Shroder (Shroder, 1978; Shroder, 1980), who developed the "process-event-response" concept in which the "process" represents the type of geomorphological process, the "event" represents the effect of the process on the tree, and the "response" represents the morphological response that the tree forms due to the disturbance (reduced growth of tree rings, formation of traumatic resin ducts, etc.).

Dendrogeomorphology has evolved from a tool for sensing and dating debris flows to a tool with which we study the frequency, spatial distribution and magnitude of debris flows and the factors that trigger them. By using environmental data on factors that affect triggering, flow, deposition and consequences (precipitation, type and volume of sediments, topography, vegetation, etc.), we can study the dynamics of recent and past events (Bollschweiler and Stoffel, 2010). However, different studies have analysed different sized events. Jakob (2005) and Stoffel (2010) have divided debris flows into different size classes. Some studies have reported lower success when dating debris flows of smaller size (Ruiz-Villanueva et al., 2010; Saez et al., 2011; ) and a higher likelihood of response via mechanical injuries and traumatic resin ducts compared to changes in growth pattern (Kogelnig-Mayer et al., 2011). Growth disturbance can also be delayed (Stoffel et al., 2013). Different studies report a different success rates, from a dating response of $40 \%$ of known events (Kogelnig-Mayer et al., 2011) to full matching and the formation of chronologies of past debris flow activity (Stoffel and Bollschweiler, $2009 \mathrm{~b})$. In this research, we tested the utility of dendrogeomorphology for dating small debris flows in the alpine and subalpine region of NW and W Slovenia. By comparing the growth pattern of trees within the debris flow fan with the growth pattern of trees in the surroundings, we aimed to (1) determine the spatial distribution of the response of affected trees within the fan, (2) compare the response between different tree species and (3) reconstruct past debris flow activity based on the detected response.

\section{METHODS}

\section{METODE}

\subsection{Description of the researched locations}

\subsection{Opis raziskovalnih območij}

In this research, we selected three locations in the W and NW Slovenia (Fig. 1), where debris flows have damaged but not uprooted trees. The highest measured burial depth was $2 \mathrm{~m}$. All three locations were on existing torrential channels without permanent water flow. Two of the locations were in direct proximity of the Soča River, while the third was in the foothills of the Vojsko Plateau, on the left bank of the Nikova Torrent.

The Javoršček research location (13³4'55", $\left.46^{\circ} 19^{\prime} 28^{\prime \prime}\right)$ is located on a NW facing slope that is predominantly covered with beech forest. The bedrock consists of limestone and dolomite. The soil is mostly leptosol or cambisol on dolomite and limestone (Forest Unit Management Plan ..., 2014). The debris flow on this location occurred after heavy rainfall in the first half of September 2015. The Srpenica research location $\left(13^{\circ} 29^{\prime} 47^{\prime \prime}, 46^{\circ} 17^{\prime} 33^{\prime \prime}\right)$ is located on a NE facing slope covered with a beech forest that includes old Scots pine trees that are remnants of an earlier successional stage. The bedrock consists mostly of limestone, and the soils are cambisol on limestone (Forest Unit Management Plan ..., 2014). The debris flow occurred on September 14,2015 . The Nikova research location (14 $\left.0^{\circ} 8^{\prime \prime}, 45^{\circ} 59^{\prime} 51^{\prime \prime}\right)$ is located on a SE slope and is covered with beech forest that includes other broad-leaved trees. The soil is cambisol on limestone (Čar, 2010; Forest Unit Management Plan ..., 2015). This event occurred in a rainy period between October 27 and November 5, 2012 (Table 1).

\subsection{Sampling and data preparation}

2.2 Zajem vzorcev na terenu in priprava podatkov

At each location we collected the following data for all the trees sampled on the debris flow fan: a) tree location ( $x$ and $y$ coordinates), b) tree species, c) diameter at breast height, d) social status, e) visible damage on roots and other parts, f) depth of sediment and damage above the ground, and g) sample cores.

With an increment borer we took two cores at breast height from every living tree on the fan, one core on each side of the tree, perpendicular to the slope (Speer, 2010). This was done in order to avoid all the mecha- 


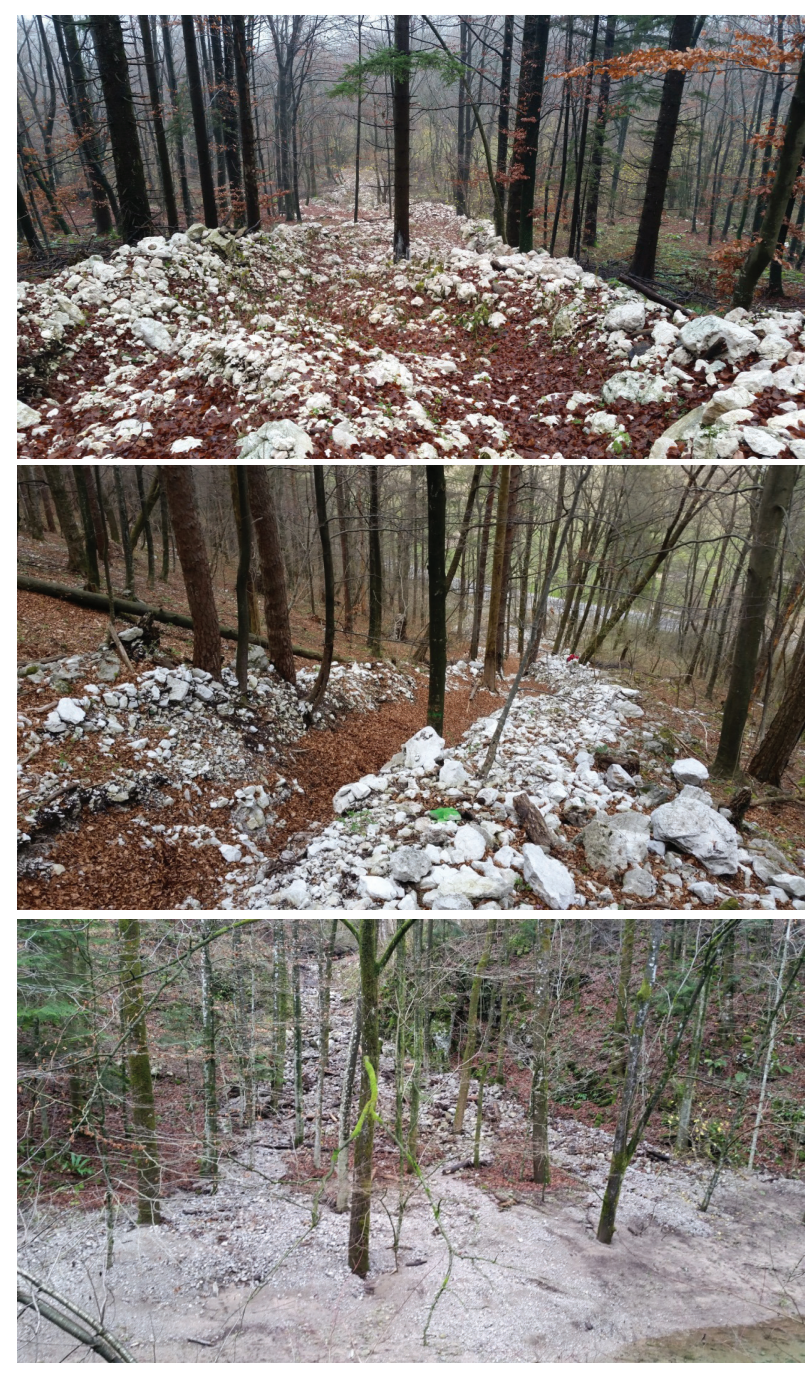

Fig. 1: Test sites (photos from top to bottom: Javoršček, Srpenica, Nikova)

nical deformations caused by the impact of the debris flow and reaction wood so that we could acquire samples that represented only tree-ring width. We also sampled five trees in the nearby location that did not show any evidence of past mass movement processes. These trees represented a control sample, giving us the growth pattern specific for the given location (Table 2).

Cores were later processed using standard dendrochronological procedures (Stokes and Smiley, 1968) involving drying, sanding, scanning, tree-ring recognition and the creation of tree-ring width chronologies.

Table 1: General characteristics of the test sites
Slika 1: Testna območja (fotografije od zgoraj navzdol: Javoršček, Srpenica, Nikova)

\subsection{Tree response recognition}

2.3 Ugotavljanje odziva dreves

To determine the response of trees to past debris flow activity, we used pointer-year analysis, one of the most commonly used methods for sensing the response of trees to extreme events (van der Maaten-Theunissen et al., 2015). This method quantifies event years at the level of a single tree and pointer years at the level of the whole sample. Since we were focusing on growth changes in recent years, we applied a method of relative growth change that compares the growth of the inspected year with the average growth of a selected

Preglednica 1: Osnovni podatki o vzorčnih lokacijah

\begin{tabular}{|l|c|c|c|}
\hline \multicolumn{1}{|c|}{ Test site } & Area of debris flow fan & Mean sediment depth & Estimated volume of deposits \\
\hline Javoršček & $3500 \mathrm{~m}^{2}$ & $0.36 \mathrm{~m}$ & $1260 \mathrm{~m}^{3}$ \\
\hline Srpenica & $2000 \mathrm{~m}^{2}$ & $0.38 \mathrm{~m}$ & $760 \mathrm{~m}^{3}$ \\
\hline Nikova & $670 \mathrm{~m}^{2}$ & $0.46 \mathrm{~m}$ & $308 \mathrm{~m}^{3}$ \\
\hline
\end{tabular}

* Mean sediment depth was calculated based on the height of the sediment above the ground at each tree location 
Table 2: Tree species frequency sampled at the study locations
Preglednica 2: Vrstna sestava vzorcev analiziranih dreves po lokacijah

\begin{tabular}{|c|c|c|c|}
\hline Tree species & Javoršček & Srpenica & Nikova \\
\hline \multicolumn{4}{|c|}{ Research sample on the fan } \\
\hline Fagus sylvatica & 19 & 7 & 19 \\
\hline Fraxinus excelsior & & 2 & 7 \\
\hline Pinus sylvestris & & 8 & \\
\hline Picea abies & 4 & & \\
\hline Fraxinus ornus & 4 & & \\
\hline Juglans regia & 2 & & \\
\hline \multicolumn{4}{|c|}{ Control sample in the nearby location } \\
\hline Control Fagus sylvatica & 5 & 5 & 5 \\
\hline Control Pinus sylvestris & & 4 & \\
\hline All sampled trees & 34 & 26 & 31 \\
\hline
\end{tabular}

number of earlier years (four in our case). This method determines event years with an abrupt change in growth (at the level of a single tree) resulting in a $40 \%$ decrease in tree-ring width or $160 \%$ increase in treering width in an inspected year as compared to previous years (Schweingruber et al., 1990). Years when 75 $\%$ of the trees in a sample show the same response are considered to be pointer years (Cropper, 1985).

Based on the assumption that a debris flow does not damage most of the trees during a single event, we found the threshold for pointer years to be too high (Kogelnig-Mayer et al., 2011). We applied the $I_{t}$ index (Shroder, 1978), which helped us to compare the number of trees that showed the response with the number of chronologies containing that year. We calculated the $I_{t}$ index with the following equation:

$$
I_{t}=\left(\sum_{i=1}^{n} R_{t}\right) /\left(\sum_{i=1}^{n} A_{t}\right) * 100 \%
$$

where $R$ is the number of responses, $A$ is the number of chronologies representing the inspected year and $n$ is number of all trees in the sample growing in year $t$.

This allowed us to obtain the relative response of the sample, especially for years in the past, where the number of chronologies were low due to the age of the trees. For the same reason, we also established a minimum number of growth disturbances (2) (Stoffel et al., 2013).

We marked years for which $I_{t}$ exceeded $10 \%$ as years with a weak response and years for which $I_{t}$ was over $40 \%$ as years with a strong response (Kaczka and Morin, 2007).

When trying to determine the response of trees to the debris flow, we searched for responses in the first vegetation period after the event occurred. Since all studied events occurred in the autumn after the end of the vegetation period, we focused on the growth in 2016 at the Javoršček and Srpenica locations and that in 2013 at the Nikova location.

\section{RESULTS}

\section{REZULTATI}

In total, we sampled 147 trees (10 different tree species), 127 on the fan and 20 in the control sample. The final analysis included 91 individual tree ring-width data points (six different tree species): $66 \%$ of the sampled trees in Javoršček, 35 \% in Srpenica and $74 \%$ in Nikova (58\% on average). The reason for this was the fact that in many cases we encountered problems with tree-ring recognition, especially in the case of Ostrya carpinifolia, Tilia cordata and Acer pseudoplatanus (Table 2).

\subsection{Detection of past debris flows}

\subsection{Datiranje preteklih drobirskih tokov}

At the Javoršček test site (29 trees, 102-year chronology length), we determined 24 years with a weak response. We did not identify any years with a strong response. For 16 years with a weak response (out of 24), the response was found only in the sample of trees growing on the fan and not in sample of reference trees (Fig. 2 ). For all of the 16 years with a weak response in the fan samples, a response was found on Fagus sylvatica trees. The disturbance was also found in four cases on Picea abies and in five cases on Fraxinus ornus. Trees of Juglans regia species did not display any growth disturbance in any of the 16 years categorised with a weak response.

For the sample at the Srpenica test site (17 trees, 132-year chronology length), we determined 10 years with a weak response. We did not find any years with a strong response. For eight out of the 10 years with a weak response, the response was found only in the sample of trees growing on the fan and not in the sam- 

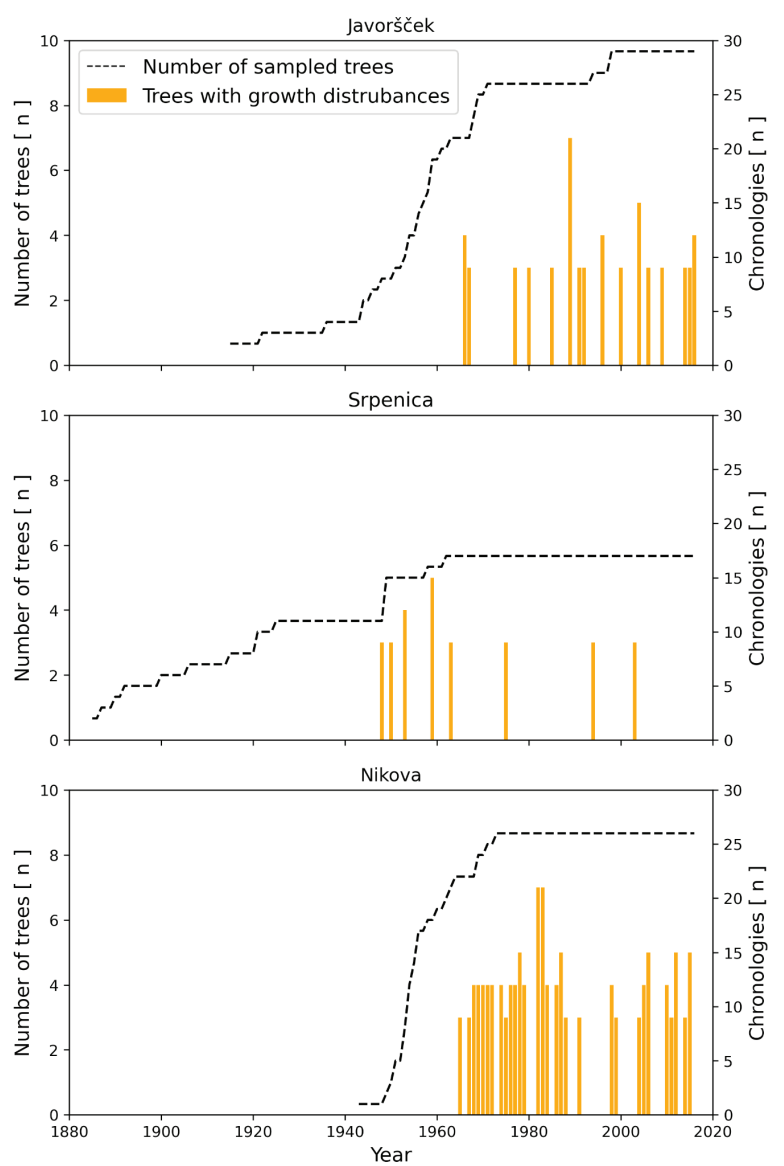

Fig. 2: Years with response detected only in the sample of trees on the debris flow fan and not in the sample of reference trees for all three locations (Javoršček, Srpenica and Nikova)

ple of reference trees (Fig. 3). For all eight years for which we determined a weak response in the fan samples, the disturbance was found on Pinus sylvestris trees. The disturbance was also found in six cases on Fagus sylvatica trees and in one case on Fraxinus excelsior.

At the Nikova test site (26 trees, 74-year chronology length), we determined 31 years with a weak response. We did not identify any years with a strong response. For the 30 years with a weak response (out of 31 ), the response was found only in the sample of trees growing on the fan and not in the sample of reference trees (Fig. 3). For 29 out of the 30 years for which we determined a weak response in the debris flow fan, the disturbance was found on Fagus sylvatica. In the case of five years with a weak response, the disturbance was also found on Fraxinus excelsior.

\subsection{Tree-ring width analysis for known debris flows}

3.2 Analiza sprememb širin branik za znane drobirske tokove

At the Javoršček test site for 2016, we found that four trees out of 29 responded with a growth change
Slika 2: Leta z odzivom, zaznanim izključno v vzorcu vseh dreves na hudourniškem vršaju in ne v vzorcu referenčnih dreves za vse tri lokacije (Javoršček, Srpenica in Nikova)

(Fig. 3), three with decreased growth and one with increased growth. The response was found on three Fagus sylvatica trees and one Picea abies tree. The $I_{\mathrm{t}}$ index value for 2016 was $13.8 \%$. We found no growth disturbances in the control sample. A weak response was also determined for 2014 and 2015.

At the Srpenica test site for 2016, we found that one Fagus sylvatica tree responded with a growth decrease. The $I_{\mathrm{t}}$ index value for 2016 was $5.9 \%$. At the Nikova site after the event in 2012, we found that one beech tree responded with a growth decrease in 2013. The $I_{\mathrm{t}}$ index value for 2013 was $3.8 \%$.

\section{DISCUSSION AND CONCLUSION \\ 4 RAZPRAVA IN SKLEPI}

For the Javoršček site, the It value of $13.8 \%$ indicated a weak response in 2016. The disturbance response included both a decrease and an increase in growth, which could be a result of the multiple effects of debris flows on tree growth (Stoffel and Bollschweiler, 2009a). No growth disturbances were found in control samples from the same year, suggesting that the factor affecting tree growth on the fan had a limited spatial 


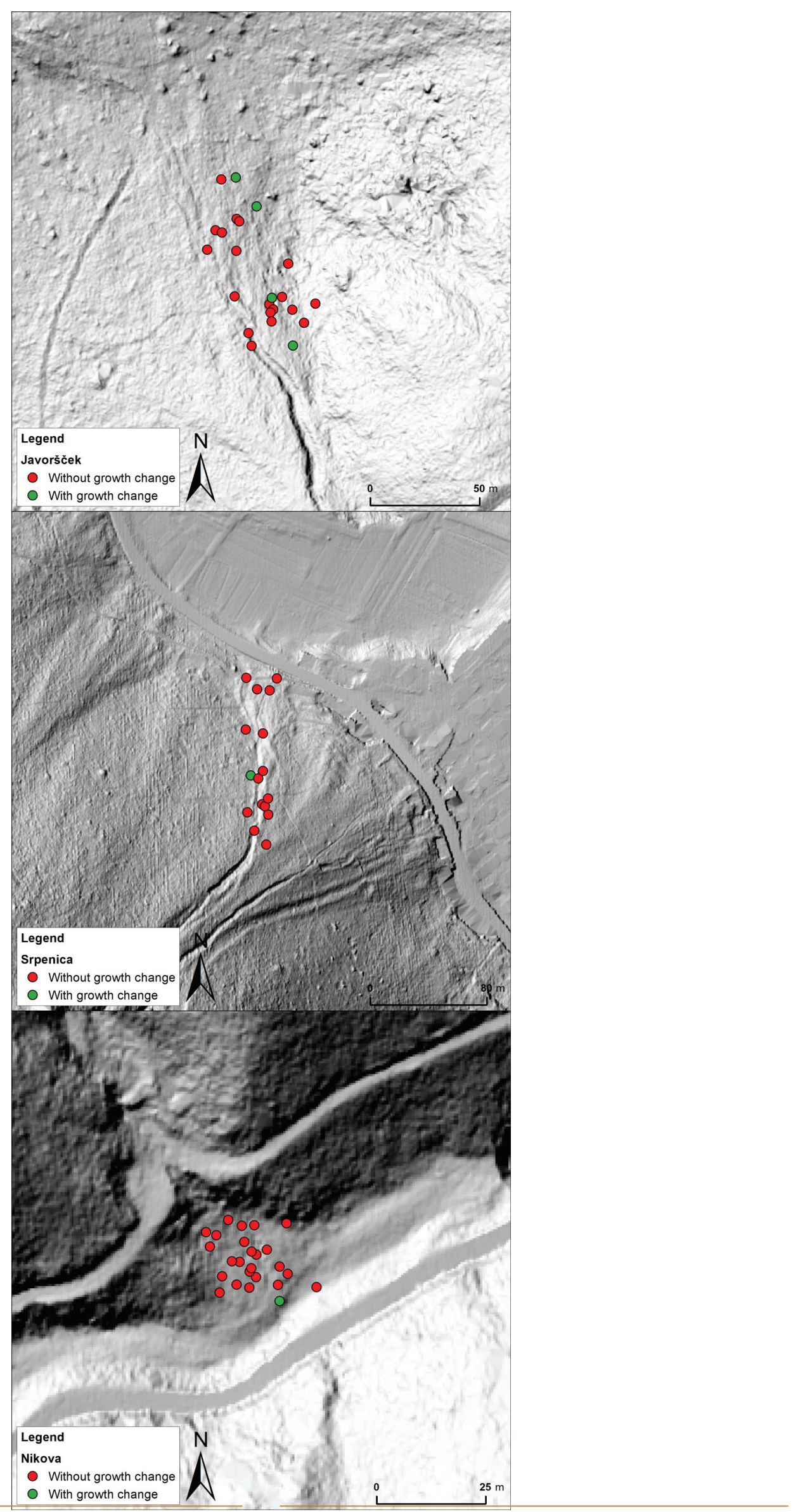

Fig. 3: Position and response of trees on the debris flow fan under Javoršček (in 2016), in Srpenica (in 2016) and in Nikova (in 2013)
Slika 3: Položaj in oznaka dreves na vršaju pod Javorščkom v letu 2016, na Srpenici v letu 2016 ter Nikovi v letu 2013 
extent (Stoffel and Bollschweiler, 2009b). We also detected similar disturbances in the sample from the fan for 2015 and 2014, which might indicate that the growth disturbing factor was already present in the past, before the event under investigation occurred. For this reason, we cannot say with certainty that the studied event caused the disturbance. At the Srpenica and $\mathrm{Ni}$ kova sites, we found no response to the studied events. In summary, we cannot say that we found a clear and unambiguous response of growth to the debris flow activity.

Different tree species showed different patterns and frequencies of growth disturbance during the study period. We found the majority of disturbances on beech trees. In Srpenica, we found that Pinus sylvestris has had a lower frequency of growth disturbances in recent years, most likely due to its old age (Kotar, 2005; Stoffel et al., 2013). In general, the comparison of response patterns was not representative because different species were represented in the sample in different proportions (some with only a few trees) and were at very different stages of development (Fagus sylvatica was much younger than Pinus sylvestris at the Srpenica test site). The reason for the smaller sample of certain species was the size of the events. On average, similar events in temperate zones tend to have a relatively small size (Zukrigl, 1989). Because of these limitations, we did not find significant differences in the response of different tree species. On the Javoršček site, both Picea abies and Fagus sylvatica trees responded, while at other sites we could not detect a response in any of the species.

Because we were unable to determine a clear and unambiguous growth response to debris flow activity, we were unable to meet the primary requirement of reconstructing the pattern of past debris flow activity.

This study confirmed the challenges of using treering width to identify and reconstruct debris flow events (Shroder, 1980). Many successful studies have been conducted in the past confirming that it is possible to detect, date and analyse debris flow activity based on the response in growth pattern and morphological changes in tree rings (Bollschweiler et al., 2008; Stoffel, 2008; Kogelnig-Mayer et al., 2011). Our research suggests that this method may not be as universally useful or reliable, especially when used to date debris flows of smaller size. The debris flows we studied were classified as small to medium in size according to various size classifications (Jakob, 2005; Stoffel, 2010). Based on a literature review, we also suggest that when dating debris flows we should focus on changes expressed in the formation of traumatic resin ca- nals (consequence of mechanical injury) and the consequent formation of callus tissue and reaction wood, rather than simply attempting to capture the response during growth disturbances. Therefore, there is potential for improvement in combining different methods of tree-ring analysis, e.g. traumatic resin canals, reaction wood and callus tissue analysis (Boelhouwers et al., 1999; Kogelnig-Mayer et al., 2011). We also confirmed statements about the limited availability of information on past events (Gärtner and Stoffel, 2002; Jakob, 2005; Arbellay et al., 2010).

\section{SUMMARY}

5 POVZETEK

$\mathrm{V}$ raziskavi smo analizirali priraščanje debeline branik za tri lokacije, za katere smo poznali čas, ko se je dogodek zgodil. Prek primerjave vzorca rasti dreves, na vršaju drobirskega toka $\mathrm{z}$ vzorcem rasti dreves $\mathrm{v}$ okolici smo poskušali zaznati odziv dreves na delovanje dejavnika, razlike v odzivu različnih drevesnih vrst in na podlagi zaznanega odziva preveriti možnost rekonstrukcije delovanja dejavnika $\mathrm{v}$ preteklosti. V vzorcu 91 dreves (6 drevesnih vrst) smo z metodo relativne spremembe rasti napravili analizo kazalnih let.

Ker smo zgolj na eni od treh lokacij zaznali šibek rastni odziv dreves na znani dogodek, v splošnem jasnega odziva na delovanje preučevanega dejavnika nismo mogli potrditi. Prav tako nam ni uspelo potrditi razlik v odzivu različnih drevesnih vrst. Ker nismo zaznali odziva na znane dogodke, nismo imeli izpolnjenih predpogojev za poskus rekonstrukcije delovanja dejavnika v preteklosti.

Z raziskavo smo potrdili kompleksnost vpliva drobirskih tokov na rast dreves in $\mathrm{v}$ ospredje postavili različne ovire pri preučevanju vpliva delovanja drobirskih tokov na rast dreves. Kot prvo lahko izpostavimo velikost vzorcev, ki so omejeni z velikostjo vršaja, kot drugo pa velikost vzorcev dreves iste vrste, ki so v primeru minoritetnih vrst lahko nereprezentativni. Potrdili smo tudi razlike v primernosti različnih drevesnih vrstza namen opravljanja dendrokronoloških analiz in domnevo o omejeni količini dostopnih informacij o preteklih dogodkih. Zaključujemo z ugotovitvijo, da je treba pri preučevanju geomorfoloških pojavov združevati različne znanstvene metode.

\section{ZAHVALE}

\section{AKNOWLEDGMENTS}

The research was made possible by the Department of Forestry and Renewable Forest Resources (Biotechnical Faculty, University of Ljubljana) and Slovenian Forestry Institute. Many individuals also contributed 
significantly to the research, including Dragan Marković, Robert Krajnc, Edvard Mendot and Jože Janež. We sincerely thank them all.

\section{REFERENCES}

\section{VIRI}

Alestalo J. 1971. Dendrochronological interpretation of geomorphic processes. Fennia, 105, 1: 1-140.

Arbellay E., Stoffel M., Bollschweiler M. 2010. Dendrogeomorphic reconstruction of past debris-flow activity using injured broad- leaved trees. Earth Surface Processes and Landforms, 35, 4: 399-406.

Boelhouwers J.N., Jager F.D., de Joode A. 1999. Application of relative-age dating methods to openwork debris flow deposits in the Cederberg mountains. Western Cape, South Africa. South African Geographical Journal, 81: 135-142.

Bollschweiler M., Stoffel M. 2010. Tree rings and debris flows: recent developments, future directions. Progress in Physical Geography, 34, 5: 625-645.

Bollschweiler M., Stoffel M., Schneuwly M.D., Bourqui K. 2008. Traumatic resin ducts in Larix decidua stems impacted by debris flows. Tree Physiology, 28: 255-263.

Čar J. 2010. Geološka zgradba idrijsko-cerkljanskega hribovja: tolmač h Geološki karti idrijsko-cerkljanskega hribovja med Stopnikom in Rovtami v merilu 1:25.000: monografija $=$ Geological Structure of the Idrija - Cerkno hills : explanatory book to the Geological map of the Idrija - Cerkljansko hills between Stopnik and Rovte 1:25.000: monograph. Ljubljana, Geološki zavod Slovenije: $127 \mathrm{pp}$

Cropper J.P. 1985. Tree - ring response functions: an evaluation by means of simulations (dendrochronology ridge regression, multicollinearity). Tucson, Arizona, The University of Arizona, University Microfilms International: $131 \mathrm{pp}$.

Forest unit management plan - unit Bovec 2014-2023. 2014. Bovec, Zavod za gozdove Slovenije, OE Tolmin: $187 \mathrm{pp}$

Forest unit management plan - unit Idrija 1 2015-2024. 2015. Idrija, Zavod za gozdove Slovenije, OE Tolmin: $181 \mathrm{pp}$.

Gärtner H., Stoffel M. 2002. Detailed mapping and dendrogeomorphological analysis of a debris flow torrent in Switzerland. V: International Congress Interpraevent 2002, in the Pacific Rim. Matsumoto, Japan, Klagenfurt, Internationale Forschungsgesellschaft Interpraevent: 199-207.

Iverson R.M. 1997. The physics of debris flows. Reviews of Geophysics, 35, 3: 245-296.

Jakob M. 2005. A size classification for debris flows. Engineering Geology, 79: 151-161.

Kaczka R.J., Morin H. 2007. The dendrochronological records of debris flow activity in SE Quebec. Trace, 5: 233-239.

Kogelnig-Mayer B., Schneuwly-Bollschweiler M., Hübl J., Rudolf-Miklau F. 2011. Possibilities and limitations of dendrogeomorphic time-series reconstructions on sites influenced by debris flows and frequent snow avalanche activity. Arctic, Antarctic, and Alpine Research, 43: 649-658.
Kotar M. 2005. Zgradba, rast in donos gozda na ekoloških in fizioloških osnovah. Ljubljana, Zveza gozdarskih društev Slovenije, Zavod za gozdove Slovenije: 500 pp.

Mikoš M. 2001. Značilnosti drobirskih tokov. Ujma, 14-15: 295-299.

Ruiz-Villanueva V., Díez-Herrero A., Bollschweiler M., Bodoque J., Ballesteros-Canovas J. 2010. Dendrogeomorphic analysis of flash floods in a small ungauged mountain catchment (Central Spain). Geomorphology, 118: 383-392.

Saez J.L., Corona C., Stoffel M., Gotteland A., Berger F., Liebault F. 2011. Debris-flow activity in abandoned channels of the Manival torrent reconstructed with LiDAR and tree-ring data. Natural Hazards and Earth System Sciences, 11: 1247-1257.

Schweingruber F.H., Eckstein D., Serre-Bachet F., Bräker O.U. 1990. Identification, presentation and interpretation of event years and pointer years in dendrochronology. Dendrochronologia, 8: 9-38.

Shroder J.F. 1978. Dendrogeomorphological analysis of mass movement on Table Cliffs Plateau, Utah. Quaternary Research, 9, 2: 168-185.

Shroder J.F. 1980. Dendrogeomorphology: review and new techniques of tree-ring dating. Progress in Physical Geography, 4, 2: 161-188.

Speer J.H. 2010. The fundamentals of tree-ring research. University of Arizona Press: 360 pp.

Stoffel M. 2008. Dating past geomorphic processes with tangential rows of traumatic resin ducts. Dendrochronologia, 25, 1: 53-60.

Stoffel M. 2010. Magnitude-frequency relationships of debris flows - a case study based on field surveys and tree-ring records. Geomorphology, 116: 67-76.

Stoffel M., Bollschweiler M. 2009a. What tree rings can tell about earth-surface processes: teaching the principles of dendrogeomorphology. Geography Compass, 3: 1013-1037.

Stoffel M., Bollschweiler M. 2009b. Tree-ring reconstruction of past debris flows based on a small number of samples - possibilities and limitations. Landslides, 6, 3: 225-230.

Stoffel M., Butler D.R., Corona C. 2013. Mass movements and tree rings: a guide to dendrogeomorphic field sampling and dating. Geomorphology, 200: 106-120.

Stokes M.A., Smiley T.L. 1968. An introduction to tree-ring dating Chicago: University of Chicago Press: 73 pp.

van der Maaten-Theunissen M., van der Maaten E., Bouriaud O. 2015. PointRes: an $\mathrm{R}$ package to analyze pointer years and components of resilience. Dendrochronologia, 35: 34-38.

Zukrigl K. 1989. Succession and regeneration in the natural forests in central Europe. V: Forests of the World: Diversity and Dynamics. Sjoegren E. (ed.). (Studies in Plant Ecology, 18). Almqvist \& Wiksell Internationa: 202-208. 